\title{
Yoga to Combat and Prevent COVID-19
}

\author{
Gopal Krushna Pal*
}

\section{Gopal Krushna Pal*}

Programme Director, Advance Centre for Yoga, Jawaharlal Institute of Postgraduate Medical Education and Research (JIPMER), Puducherry, INDIA.

\section{*Correspondence}

\section{Dr. G K Pal}

Editor in-Chief, IJCEP,

Programme Director, Advance Centre for Yoga, Jawaharlal Institute of Postgraduate Medical Education and Research (JIPMER), Puducherry, INDIA.

Phone: +91-9344291160

Email: drgkpal@gmail.com

\section{History}

- Submission Date: 15-04-2020;

- Review completed: 24-05-2020;

- Accepted Date: 12-06-2020.

DOI : 10.5530/ijcep.2020.7.2.12

Article Available online

http://www.ijcep.org

\section{Copyright}

(C) 2020 Phcog.Net. This is an openaccess article distributed under the terms of the Creative Commons Attribution 4.0 International license.
The COVID-19 pandemic is a global crisis. The rapid spread of COVID-19 around the world and subsequent lockdown in almost all countries have resulted the entire population being forced into confinement. Along with isolation due to lockdown, financial deficiency in the family, business slowdown, job insecurity, salary cut-down, the fear of acquiring infection and uncertainty of children education and their future during COVID have culminated in a life full of tremendous stress. Combining work while living in the family and working at home has thrown up challenges hitherto unnoticed and undocumented. While it will take time to gauge the gravity of the impact on society's mental and emotional health, exercise, yoga, music, dance and art are the disciplines that have offered promises on how to maintain one's physical and emotional equilibrium.

\section{All Life is Yoga}

The great Yogi and Philosopher Sri Aurobindo has said, 'All life is Yoga'. The entire life of a being, irrespective of gender, age, responsibilities and nature of job, should be the expression of happiness attained through works. Therefore, the ancient Indian practice has emphasized not only to improve physical but also mental health and overall wellbeing. The ancient sages would retreat into forest and mountains to practice yoga sadhana, to keep aloof from the disturbances in the world. But with this, the family and society as a whole was neglected and remain unchanged. But retiring into isolation is neither possible nor desirable in the present life. The entire life has to be changed as a part of community life. The COVID-19 crisis gave us an opportunity to be closer with the family and practice yoga to keep the family happy and healthy. The main objective is to build herd immunity of the community through practising yoga every day, to boost the overall health of the society and thereby prevent the community transmission of COVID and to facilitate the recovery of infected people in the society.

\section{The Yoga Schedule}

One can practice about 45 min yoga in the morning and $45 \mathrm{~min}$ in the evening. In the morning, one can start with some free-hand stretching exercises, 6 to 8 rounds of the surya namaskar. Then a few rounds of four to five simple asanas forward bending and backward bending asanas, followed by practice of pranayamas for about $15 \mathrm{~min}$. This will help maintain flexibility and improve overall health. ${ }^{[1]}$ Asanas can be ushtrasana (camel pose), markatasana (spinal twist), padmasana (lotus posture), pawan muktasana (air release posture), gomukhasana (cow face pose), vrikshasana (tree pose), matsyasan (fish pose), dhanurasan (bow pose), vajrasan (thunderbolt pose) and titliasan (butterfly pose) may be practised. At the end, practicing shavasana (corpse posture) and yoga nidra (sleeping consciously with body relaxation) helps to relieve anxiety or stress. A round of pranayamas such as anulom-vilom (alternate nostril breathing), kapal bhati (the shining forehead), bhastrika (bellow's breath), chandra-nadi or chandra-bhedana (left nostril breath), surya-nadi or surya-bhedana (right nostril breathing), bhramari (humming bee breath), shitali pranayama (cooling breath) are very helpful to attain peace of mind. ${ }^{[2]}$ After pranayama, the practitioner should spend about $10 \mathrm{~min}$ in dhyana (meditation).

As yoga is to inculcate right attitude to life, its regular practice helps attain discipline in life. During the lockdown, the primary task is to contribute and share the burden of domestic work, which should not fall only on the woman. Yoga brings about selfawareness and discipline, in which surya namaskar and asana bring physical flexibility and pranayamas and meditation are tools for calmness of mind and anger management.

\section{Physiological Basis}

Yoga is a great tool to improve respiratory health and immunity, both of which are involved in the prevention and healing from COVID-19.

Surya namaskar or sun salutation is a series of 12 poses (each one an asana) performed synchronizing the breathing with body movement. ${ }^{[3]}$ Practice of sun salutations benefits muscles, ligaments and joints and improves flexibility of vertebral joints. In this, the practice of alteration in body posture, controlled breathing and relaxations in-between emphasizes breath and body awareness. Various asanas improve suppleness of the body, spinal flexibility and immunity. Pranayamas improve vagal tone that is essential not only to boost the heart functions and other cardiovascular health, but also to combat the effects of stress on body. ${ }^{[4,5]}$ Bhramari pranayama (Humming breathing of low-pitch character) has been reported to cause a 15 -fold increase in nitric oxide secretion compared with quiet exhalation. ${ }^{[6]}$ 


\section{International Yoga Day, 2020}

The $21^{\text {st }}$ June is celebrated as the International Yoga Day throughout the globe. This date is the longest day of the year in the northern hemisphere and has special significance in many parts of the world. June 21 is the day of the summer solstice when the tilt of a planet's axis in the northern hemisphere is most inclined towards the star that it orbits. June 21 is considered the longest day of the year with the sun rising early and setting late for the northern hemisphere. Thus, the summer solstice is also considered as an important day in Indian mythology as it marks an event that could be considered the start of Yogic science.

The theme of International Yoga Day, 2020 is 'Yoga at Home and Yoga with Family'. While the social distancing measures adopted by countries to fight the COVID-19 pandemic have shut down yoga centers and other common spaces for practice, yoga practitioners have turned to home practice and online yoga resources. Yoga is a powerful tool to deal with the stress of uncertainty and isolation, as well as to maintain physical well-being. The COVID-19 pandemic means that many of us are staying at home and sitting down more than we usually do. It's hard for lot of us to do the sort of exercise we normally do. It's even harder for people who don't usually do a lot of physical exercise. But at a time like this, it's very important for people of all ages and abilities to be as active as possible. Therefore, the 'Yoga at Home and Yoga with Family' is the best means to combat COVID problems and to prevent spread of COVID infection.

\section{REFERENCES}

1. Pal GK, Pal P, Nanda N. Physiology of Yoga and Prevention of Aging. In: Comprehensive Textbook of Medical Physiology. $2^{\text {nd }}$ Ed. New Delhi: Jaypee Brothers Medical Publishers. 2019. p.1359-74.

2. Karthik PS, Chandrasekhar M, Ambareesha K, Nikhil C. Effect of Pranayama and Suryanamaskar on Pulmonary Functions in Medical Students. J Clin Diagn Res. 2014;8:BC04-6.

3. Bhutkar MV, Bhutkar PM, Taware GB, Surdi AD. How Effective Is Sun Salutation in Improving Muscle Strength, General Body Endurance and Body Composition? Asian J Sports Med. 2011;2:259-66.

4. Pal GK. Yoga and heart rate variability. Int J Clin Exp Physiol. 2015;2:2-9.

5. Pal GK. Effects of pranayama on cardiovascular health. Int J Clin Exp Physiol. 2016;3:57-8.

6. Weitzberg E, Lundberg JON. Humming Greatly Increases Nasal Nitric Oxide. Am J Respir Crit Care Med. 2002;166:144-5.

Cite this article: Pal GK. Yoga to Combat and Prevent COVID-19. Int J Clin Exp Physiol. 2020;7(2):46-7. 